\title{
A Grey Relational Analysis of the Influence Factors of Tourism Industry in Guangdong Province
}

\author{
TongYu ${ }^{a}$,ChunshangW $u^{b}$ \\ He Yuan Polytenic, China \\ aemail: 86282557@qq.com, bemail: 30052410@qq.com
}

\begin{abstract}
Keywords: Guangdong; tourism; grey relational analysis.
Abstract. This article launched grey system theory to analyze the tourism industry in Guangdong Province from 2005 to 2014, which indicated that the regional economy development level is the most influencing factors of Guangdong tourism industry. The article proposed policies and suggestions for the rapid growth of the tourism industry in Guangdong by maintaining sustainable and stable development of Guangdong economy, promoting coordinated development of the tourism industry in east and northwest Guangdong, implementing concentrated improvement strategy.This template explains and demonstrates how to prepare your camera-ready paper for Trans Tech Publications. The best is to read these instructions and follow the outline of this text. .
\end{abstract}

\section{Introduction}

Guangdong is a major tourism province in our country all the time. Especially in recent years, Guangdong has been promoting transformation and upgrading of tourism with all its strength, the tourism has been growing rapidly with good development trend, major tourist economy indexes such as total tourist income, tourist foreign currency earnings, the number of inbound tourists staying overnight received, and the number of star hotels has been ranking first in China which all show the powerful strength of tourism of Guangdong and establish the solid foundation of building a province with strong tourism industry. Tourism industry is in relation to many industries. To become a province with strong tourism industry, Guangdong province has to understand the influence factors relating to tourism development precisely. To provide theoretical foundation for great-leap-forward development of Guangdong tourism, the paper makes correlation degree analysis applying Grey Theory.

\section{Empirical Analysis}

Build Reference Sequence.Tourism industry is an industry of great integrity. To show overall development situation of tourism industry, the index called tourist income is often used to judge in the industry. The index of total tourist income is also used as a reference sequence of the development of Guangdong tourism in this article which is $Y=\{Y(k) \mid k=1,2, \Lambda, n\}$. See sheet 1 for details of the reference sequence.

\begin{tabular}{|c|c|c|c|c|c|c|c|c|c|c|}
\hline Year & 2005 & 2006 & 2007 & 2008 & 2009 & 2010 & 2011 & 2012 & 2013 & 2014 \\
\hline $\begin{array}{l}\text { Total tourist income } \\
\text { (hundred million } \\
\text { RMB) }\end{array}$ & 1882.6 & 2120.1 & 2455.06 & 2668 & 3068.39 & 3809.44 & 4835.27 & 5794.74 & 6716.69 & 7850.56 \\
\hline
\end{tabular}

Data resource: Statistic Yearbook of Guangdong from 2006 to 2015

Build Comparison Sequence.There are many influence factors of tourism. A scientific index system is needed to find out some key influence factors of Guangdong tourism. Referring to related literature and taking physical truth of Guangdong province into consideration, the article establishes 8 indexes including GDP, GDPPC, Urban Residents Disposable Income, and Volume of Passenger 
Transportation as comparison sequence- $\mathrm{Xi}=\{\mathrm{Xi}(\mathrm{k}) \mid \mathrm{k}=1,2, \Lambda, \mathrm{n}\}, \mathrm{i}=1,2, \Lambda, \mathrm{m}$. See sheet 2 for details of the comparison sequence.

Sheet 2 Comparison Sequence of Influence Factors of Guangdong Tourism Development

\begin{tabular}{|c|c|c|c|c|c|c|c|c|c|c|}
\hline Year & 2005 & 2006 & 2007 & 2008 & 2009 & 2010 & 2011 & 2012 & 2013 & 2014 \\
\hline $\begin{array}{c}\text { Number of Students in Regular } \\
\text { Higher Educational Institutions (ten } \\
\text { thousand) }\end{array}$ & 87.47 & 100.86 & 111.97 & 121.6 & 133.41 & 142.66 & 152.73 & 161.68 & 171 & 179.42 \\
\hline Number of Star Hotel & 1128 & 1207 & 1171 & 1165 & 1181 & 1209 & 1156 & 1092 & 1083 & 1012 \\
\hline Passenger Capacity (ten thousand) & 161357 & 197314 & 206504 & 484161 & 428705 & 467049 & 522095 & 586299 & 175109 & 193299 \\
\hline $\begin{array}{l}\text { Volume of Passenger Transportation } \\
\text { (hundred million people/kilometer) }\end{array}$ & 2043.23 & 2245.37 & 2626.7 & 2552 & 2853.3 & 3342.2 & 3851.8 & 4372.1 & 3538 & 3966.5 \\
\hline $\begin{array}{l}\text { Coverage Rate of the Population of } \\
\text { Radio and TV Programs (\%) }\end{array}$ & 96.25 & 96.55 & 97.15 & 95.75 & 97.6 & 98 & 98 & 99.9 & 99.9 & 99.9 \\
\hline $\begin{array}{l}\text { GDP of Guangdong Province } \\
\text { (hundred million RMB) }\end{array}$ & 22557.4 & 26587.8 & 31777 & 36797 & 39482.56 & 46013 & 53210 & 57068 & 62475 & 67810 \\
\hline $\begin{array}{l}\text { GDPPC of Guangdong Province } \\
\text { (RMB) }\end{array}$ & 24647 & 28747 & 33890 & 38748 & 41166 & 44736 & 50807 & 54095 & 58833 & 63469 \\
\hline $\begin{array}{c}\text { Unban Per Capita Disposable } \\
\text { Income (RMB) }\end{array}$ & 14769.9 & 16015.6 & 17699 & 19733 & 21574.72 & 23898 & 26897 & 30227 & 29537 & 32148 \\
\hline
\end{tabular}

Data resource: from sorting data of Statistic Yearbook of Guangdong from 2006 to 2015

Application of Dimensionless Method.See sheet 3 for standard data sequence coming from dimensionless method with equalization method: $x_{i}(k)=\frac{X_{i}(k)}{X_{i}(l)}, k=1,2, \Lambda, n ; i=0,1,2, \Lambda, m$

Sheet 3 Reference Sequence and Comparison Sequence after Applying Dimensionless Method

\begin{tabular}{|c|c|c|c|c|c|c|c|c|c|c|}
\hline \\
\hline Year & 2005 & 2006 & 2007 & 2008 & 2009 & 2010 & 2011 & 2012 & 2013 & 2014 \\
\hline Total Tourist Income & 0.456932 & 0.515 & 0.5959 & 0.6476 & 0.74474 & 0.9246 & 1.17359 & 1.406 & 1.6302 & 1.9054 \\
\hline GDP of Guangdong Province & 0.5083 & 0.599 & 0.7161 & 0.8292 & 0.8897 & 1.0369 & 1.199 & 1.286 & 1.4078 & 1.528 \\
\hline $\begin{array}{l}\text { GDPPC of Guangdong Province } \\
\text { (RMB) }\end{array}$ & 0.561259 & 0.655 & 0.7717 & 0.8824 & 0.93743 & 1.01872 & 1.15697 & 1.232 & 1.3397 & 1.4453 \\
\hline $\begin{array}{c}\text { Unban Per Capita Disposable } \\
\text { Income (RMB) }\end{array}$ & 0.635267 & 0.689 & 0.7613 & 0.8487 & 0.92795 & 1.02786 & 1.15688 & 1.3 & 1.2704 & 1.3827 \\
\hline $\begin{array}{c}\text { Volume of Passenger } \\
\text { Transportation (hundred million } \\
\text { people/kilometer) }\end{array}$ & 0.650891 & 0.715 & 0.8368 & 0.8129 & 0.90895 & 1.0647 & 1.22704 & 1.393 & 1.1271 & 1.2636 \\
\hline Passenger Capacity (ten thousand) & 0.471543 & 0.577 & 0.6035 & 1.4149 & 1.25283 & 1.36489 & 1.52575 & 1.713 & 0.5117 & 0.5649 \\
\hline Number of Star Hotel & 0.989127 & 1.058 & 1.0268 & 1.0216 & 1.0356 & 1.06015 & 1.01368 & 0.958 & 0.9497 & 0.8874 \\
\hline $\begin{array}{l}\text { Number of Students in Regular } \\
\text { Higher Educational Institutions (ten } \\
\text { thousand) }\end{array}$ & 0.641826 & 0.74 & 0.8216 & 0.8926 & 0.97892 & 1.04679 & 1.12068 & 1.186 & 1.2547 & 1.3165 \\
\hline $\begin{array}{l}\text { Coverage Rate of the Population of } \\
\text { Radio and TV Programs (\%) }\end{array}$ & 0.983146 & 0.986 & 0.9923 & 0.978 & 0.99694 & 1.00102 & 1.00102 & 1.02 & 1.0204 & 1.0204 \\
\hline
\end{tabular}

Calculation of Correlation Coefficient.First is to calculate the absolute difference of comparison sequences and reference sequences $\Delta_{i}=\left|Y_{i}-X_{i}\right|$, to reach the output in sheet 4 . We can see from sheet 4 that the maximum value is 1.3405 and the minimum value is 0.0076 .Second is to assign 0.5 to $\rho$ and get the Correlation Coefficient Matrix in sheet 5 according to the formula: 


$$
\xi_{i}(k)=\frac{\min _{i} \min _{k} \Delta_{i}(k)+\rho \max _{i} \max _{k} \Delta_{i}(k)}{\Delta_{i}(k)+\rho \max \max _{i} \Delta_{i}(k)} .
$$

Sheet 4 Difference Value between Comparison Sequence and Reference Sequence

\begin{tabular}{|c|c|c|c|c|c|c|c|c|c|c|}
\hline Year & 2005 & 2006 & 2007 & 2008 & 2009 & 2010 & 2011 & 2012 & 2013 & 2014 \\
\hline GDP of Guangdong Province & 0.0514 & 0.0845 & 0.1202 & 0.1816 & 0.145 & 0.1122 & 0.0254 & 0.121 & 0.2224 & 0.3774 \\
\hline $\begin{array}{c}\text { GDPPC of Guangdong Province } \\
\text { (RMB) }\end{array}$ & 0.104326 & 0.14005 & 0.1759 & 0.2348 & 0.19269 & 0.09412 & 0.01661 & 0.175 & 0.2905 & 0.4601 \\
\hline $\begin{array}{c}\text { Unban Per Capita Disposable } \\
\text { Income (RMB) }\end{array}$ & 0.178334 & 0.17427 & 0.1654 & 0.2012 & 0.18321 & 0.10326 & 0.0167 & 0.106 & 0.3598 & 0.5227 \\
\hline $\begin{array}{c}\text { Volume of Passenger } \\
\text { Transportation (hundred million } \\
\text { people/kilometer) }\end{array}$ & 0.193959 & 0.20071 & 0.2409 & 0.1654 & 0.16421 & 0.1401 & 0.05346 & 0.014 & 0.5031 & 0.6419 \\
\hline Passenger Capacity (ten thousand) & 0.014611 & 0.06205 & 0.0076 & 0.7673 & 0.50809 & 0.44028 & 0.35216 & 0.307 & 1.1185 & 1.3405 \\
\hline Number of Star Hotel & 0.532194 & 0.54382 & 0.431 & 0.374 & 0.29086 & 0.13555 & 0.15991 & 0.449 & 0.6806 & 1.018 \\
\hline $\begin{array}{l}\text { Number of Students in Regular } \\
\text { Higher Educational Institutions } \\
\text { (ten thousand) }\end{array}$ & 0.184894 & 0.2255 & 0.2257 & 0.245 & 0.23418 & 0.12219 & 0.0529 & 0.22 & 0.3756 & 0.5889 \\
\hline $\begin{array}{l}\text { Coverage Rate of the Population } \\
\text { of Radio and TV Programs (\%) }\end{array}$ & 0.526214 & 0.47163 & 0.3965 & 0.3305 & 0.2522 & 0.07642 & 0.17256 & 0.386 & 0.6098 & 0.885 \\
\hline
\end{tabular}

Sheet 5 Correlation Coefficient Matrix of Guangdong Tourism Industry

\begin{tabular}{|c|c|c|c|c|c|c|c|c|c|c|}
\hline Year & 2005 & 2006 & 2007 & 2008 & 2009 & 2010 & 2011 & 2012 & 2013 & 2014 \\
\hline GDP & 0.928321 & 0.88048 & 0.8343 & 0.7651 & 0.80496 & 0.84416 & 0.96948 & 0.834 & 0.7252 & 0.6052 \\
\hline GDPPC (RMB) & 0.854239 & 0.8106 & 0.7711 & 0.7139 & 0.75386 & 0.86758 & 0.98435 & 0.772 & 0.6671 & 0.5561 \\
\hline $\begin{array}{c}\text { Unban Per Capita Disposable } \\
\text { Income (RMB) }\end{array}$ & 0.768526 & 0.77279 & 0.7823 & 0.7455 & 0.76348 & 0.85561 & 0.9842 & 0.852 & 0.6168 & 0.5239 \\
\hline $\begin{array}{c}\text { Volume of Passenger } \\
\text { Transportation (hundred million } \\
\text { people/kilometer) }\end{array}$ & 0.752584 & 0.7459 & 0.7084 & 0.7823 & 0.78353 & 0.81055 & 0.92516 & 0.989 & 0.5336 & 0.4719 \\
\hline $\begin{array}{c}\text { Passenger Capacity (ten } \\
\text { thousand) }\end{array}$ & 0.987788 & 0.91237 & 1 & 0.4273 & 0.53109 & 0.56712 & 0.62195 & 0.654 & 0.3379 & 0.2984 \\
\hline Number of Star Hotel & 0.51936 & 0.51389 & 0.5725 & 0.6074 & 0.6668 & 0.81585 & 0.78822 & 0.562 & 0.4572 & 0.3594 \\
\hline $\begin{array}{l}\text { Number of Students in Regular } \\
\text { Higher Educational Institutions } \\
\text { (ten thousand) }\end{array}$ & 0.761752 & 0.72234 & 0.7221 & 0.7048 & 0.71443 & 0.83185 & 0.926 & 0.727 & 0.6064 & 0.4937 \\
\hline $\begin{array}{l}\text { Coverage Rate of the Population } \\
\text { of Radio and TV Programs (\%) }\end{array}$ & 0.522222 & 0.54987 & 0.5931 & 0.6371 & 0.69857 & 0.89174 & 0.77459 & 0.6 & 0.4849 & 0.3925 \\
\hline
\end{tabular}

Calculation of Correlation Coefficient. According to the formula

$$
r_{i}=\frac{1}{n} \sum_{k=1}^{n} \xi_{i}(k), k=1,2, \Lambda, n \text {, }
$$

, we can calculate the correlation degree of comparison sequences and total tourist income. See sheet 6 for details.

\begin{tabular}{|c|c|c|c|c|c|c|c|c|}
\hline \multicolumn{9}{|c|}{ Province } \\
\hline $\begin{array}{l}\text { Comparison } \\
\text { Sequence }\end{array}$ & $\begin{array}{l}\text { GDP of } \\
\text { Guangdong } \\
\text { Province }\end{array}$ & $\begin{array}{l}\text { GDPPC of } \\
\text { Guangdong } \\
\text { Province }\end{array}$ & $\begin{array}{c}\text { Volume of } \\
\text { Passenger } \\
\text { Transportation }\end{array}$ & $\begin{array}{c}\text { Number of Students in } \\
\text { Regular Higher } \\
\text { Educational } \\
\text { Institutions }\end{array}$ & $\begin{array}{l}\text { Unban Per } \\
\text { Capita } \\
\text { Disposable } \\
\text { Income }\end{array}$ & $\begin{array}{l}\text { Passenger } \\
\text { Capacity }\end{array}$ & $\begin{array}{c}\text { Coverage Rate of the } \\
\text { Population of Radio and } \\
\text { TV Programs }\end{array}$ & Number of Star Hotel \\
\hline $\begin{array}{c}\text { Correlation } \\
\text { Degree }\end{array}$ & 0.8704 & 0.7995 & 0.7813 & 0.7463 & 0.7148 & 0.6711 & 0.6391 & 0.6115 \\
\hline Ranking & 1 & 2 & 3 & 4 & 5 & 6 & 7 & 8 \\
\hline
\end{tabular}

Sheet 6 Grey Correlation Degrees and Ranking of Influence Factor of Tourism in Guangdong

Result Analysis.As we can see from sheet 6, the total tourist income of Guangdong province most relates to local economic development indexes of GDP and GDPPC. The correlation degrees are 0.8704 and 0.7995 ranking first and second respectively; as an influence factor of the accessibility of tourist destinations, traffic has a great effect on tourist income and is a major influence factor of total tourist income, in which the correlation degrees between total tourist income and volume of 
passenger transportation and passenger capacity are 0.7813 and 0.6711 , ranking third and sixth respectively; the number of students in higher educational institutes also has relatively significant influence to tourist income with a correlation degree of 0.7463 ranking fourth. This indicates that, on one hand, people who receive higher education are more willing to travel, and on the other hand, Guangdong tourism requires higher standard of service quality in tourism; in addition, unban per capita disposable income is also a big influence factor with a correlation degree of 0.7148 ranking fifth which indicates that residents in Guangdong province have a strong desire to travel and that the tourist income is affected significantly by tourists in the province; while the correlation degree between tourist income and coverage rate of the population of radio and TV programs and the number of star hotel are relatively low which are 0.6391 and 0.6115 ranking the last but one and the last one respectively indicating that the establishment of star hotel in Guangdong has lagged behind the development of its tourism, that the utilization ratio of information resources is low, that the propaganda for tourism is not satisfying leading to poor contribution to tourism made by information resources.

\section{Conclusion}

Sheet 6 shows that the ranking of grey correlation degree of influence factor of tourism in Guangdong province from high to low is that: GDP of Guangdong province, GDPPC of Guangdong province, volume of passenger transportation, number of students in regular higher educational institutions, unban per capita disposable income, passenger capacity, coverage rate of the population of radio and TV programs and the number of star hotel, among which GDP of Guangdong province and GDPPC are in the first two positions showing that the regional economy development level is the most important influence factor of tourism development in Guangdong and that the strong economic strength of Guangdong province has great driving effect on its tourism industry.

\section{Policy Suggestion}

To ensure continuous and stable development of Guangdong economy and to provide inexhaustible power for the development of tourism industry.In recent years, economy of Guangdong province has been faced with more complex and changeable difficulties and challenges from domestic and international economic situation. Guangdong economy should adapt to the New Normal initiatively, implement innovation-driven development strategy, hang on to the opportunity of "Made in China 2025 Strategy" carried out in our country, accelerate economy transformation and upgrading, actively promote the "One Belt and One Road" construction, strengthen domestic and international regional cooperation ${ }^{[1]}$ and ensure continuous and stable development of Guangdong economy to provide inexhaustible power for the development of tourism industry.

To promote coordinated development of tourism industry in Pearl River Delta and the eastern, western and northern regions of Guangdong province.The Pearl River Delta with a strong tourism industry should bring its superiority of capital and talents into full play, radiate and drive development of the relatively backward eastern, western and northern regions of Guangdong province and finally become a powerful engine for tourism development of the whole province. To promote tourism cooperation in the province greatly, to create the pro-poor tourism mode, to actively support key project construction in tourism developing zones, to cultivate excellent tourism projects of developing zones and to buildup tourism attraction and competition of developing zones. [2]

To carry out cluster development strategy. To build tourism industrial park and distinctive district, create competitive industry cluster and achieve scale benefit, each region should integrate tourism resources according to industrialization level, development foundation, cultural background and other conditions. For example: Guangzhou, Shenzhen, Zhuhai and other cities can stress development of theme park, Shaoguan, Meizhou, Heyuan and other mountain cities tourism 
industrial cluster and Zhanjiang, Jiangmen, Shantou, Chaozhou and other cities coastal tourism industrial park ${ }^{[3]}$.

\section{References:}

[1]Chen Yanling: The International and Domestic Environmental Analysis of Guangdong's Economic Development under the New Normal. Guangdong Economy, 2015, (8),p. 32-37.

[2]Tourist Administration of Guangdong Province: Integration Planning of Tourism Industry in the Pearl River Delta (2011-2015).http://www.gdta.gov.cn/xxgk/ghtj/22384.html.

[3] Tourist Administration of Guangdong Province, Tourism Development Research Center of Guangdong Province: Overall Planning of Tourism Development of Guangdong Province (2011-2020). Beijing: China Travel \& Tourism Press, (2014). 